\title{
DIAGNÓSTICO DE FOCOS E CICATRIZES DE INCÊNDIO EM PERÍODO SECO DO BIOMA AMAZÔNIA NO NORDESTE DO ESTADO DE RONDÔNIA
}

\author{
Aline Biasoli Trentin ${ }^{1}$ \\ Carline Biasoli Trentin ${ }^{2}$ \\ Juliane Soller Moreira ${ }^{3}$
}

Resumo: O objetivo deste trabalho foi realizar a análise de focos de incêndio e de áreas queimadas durante o período seco do bioma Amazônia nos anos 2018 e 2019, considerando um recorte espacial no nordeste do estado de Rondônia. Os procedimentos consistiram na produção de mapas de focos de incêndio a partir de dados obtidos do banco de dados de queimadas do INPE e no mapeamento do uso e cobertura da terra através de imagens do satélite CBERS 4 - MUX, para a identificação de cicatrizes de incêndios para cada período de estudo. Os resultados permitiram identificar o aumento de focos de incêndio no período seco em 2019 em comparação a 2018. Os mapas de uso e cobertura da terra demonstraram mudanças bruscas na paisagem entre os meses de julho e agosto de 2019. Portanto, constatou-se a eficiência das geotecnologias no monitoramento de incêndios e mudanças de uso da terra nessa área.

Palavras-chave: Geoprocessamento, Uso e cobertura da terra, Queimadas.

\section{DIAGNOSIS OF OUTBREAKS AND FIRE SCARS IN DRY PERIOD OF THE AMAZON BIOMA IN THE NORTHEAST OF THE STATE OF RONDÔNIA}

\begin{abstract}
We analyzed fire outbreaks and burned areas during the dry period of the Amazon biome in the years 2018 and 2019, considering a spatial cutout in the northeast of the state of Rondônia. The procedures consisted in the production of maps of fire outbreaks from data obtained from the INPE burn database and in the mapping of land use and land cover through images of the CBERS 4 - MUX satellite, for the identification of fire scars for each study period. The results allowed identifying the increase in fire outbreaks in the dry period in 2019 compared to 2018. Land use and land cover maps showed sudden changes in landscape between July and August 2019. Therefore, it was verified the efficiency of geotechnologies in monitoring fires and land use changes in this area.
\end{abstract}

Keywords: Geoprocessing, Land use and land cover, Burns.

\footnotetext{
${ }^{1}$ Professora da Universidade Federal do Pampa (UNIPAMPA). Email: abtrentin@ gmail.com

${ }^{2}$ Professora do Curso de Geografia da Universidade Federal do Mato Grosso - Campus Araguaia. Email: carlinebtrentin@gmail.com

${ }^{3}$ Graduanda em Engenharia Florestal pela Universidade Federal do Pampa (UNIPAMPA). Email: julianesoller@ hotmail.com
} 


\section{INTRODUÇÃO}

O bioma Amazônia é localizado na porção norte da América do Sul. Mais de $60 \%$ de sua área, cerca de 4,2 milhões $\mathrm{km}^{2}$, está em território brasileiro. Desta forma, o Brasil é o país com maior extensão desta cobertura vegetal (BRASIL, 2008). Em território brasileiro abrange os Estados do Acre, Amapá, Amazonas, Mato Grosso, Pará, Roraima, Rondônia e Tocantins e, parcialmente, o Estado do Maranhão (a oeste do Meridiano 44은 (MARTHA JÚNIOR; CONTINI; NAVARRO, 2011).

O fogo é considerado um dos fatores de maior ameaça à integridade biológica da maior e mais rica floresta tropical do mundo, correndo o risco de ser convertida em fragmentos empobrecidos e submetidos às plantas invasoras, resultantes dos efeitos de seca e de atividades antrópicas, os quais diminuem a resistência da floresta às queimas. Sendo assim, os danos causados à estas florestas são inestimáveis (NEPSTADE; MOREIRA; ALENCAR, 1999).

Devido à grande extensão territorial, como ocorre no Brasil, o monitoramento dos incêndios florestais, por meio da utilização de imagens de satélites, é a forma mais barata e eficiente de detecção. Assim, atividades como a avaliação dos efeitos do fogo, só são viáveis através do monitoramento por satélite. Consequentemente, as informações devem ser confiáveis e de qualidade (BATISTA, 2004).

Assim, o sensoriamento remoto tem papel fundamental, ao viabilizar o estudo do ambiente terrestre por meio das interações entre a radiação eletromagnética e substâncias componentes do planeta, de acordo com o comportamento espectral de cada alvo para a interpretação dos fenômenos (GRANEMANN; CARNEIRO, 2009).

O Programa Queimadas, desenvolvido no Instituto Nacional de Pesquisas Espaciais (INPE), é responsável pelo monitoramento operacional de focos de queimadas e de incêndios florestais detectados por satélites. Ainda que os satélites indiquem apenas uma fração do número real de focos de queimada e incêndios florestais, os resultados gerados permitem analisar as tendências espaciais e temporais dos focos (INPE, 2019; EMBRAPA, 2019).

Ainda, através de imagens de satélite como as obtidas pelo satélite CBERS, por exemplo, é possível reconhecer os tipos de usos e coberturas da terra pela análise visual ou pela classificação digital da imagem. Na classificação de imagens é possível identificar estas coberturas conforme a quantidade de luz refletida dos objetos, sendo adequados para mapear as cicatrizes deixadas na vegetação pelos incêndios (NEPSTADE; MOREIRA; ALENCAR, 1999).

Diante do exposto, o objetivo deste trabalho foi realizar a análise de focos de incêndio e de cicatrizes de áreas queimadas durante o período seco do bioma Amazônia, considerando um recorte espacial no nordeste do estado de Rondônia, nos anos de 2018 e 2019.

\section{MATERIAL E MÉTODOS}

A área de estudo refere-se à cena do satélite CBERS 4 - MUX correspondente a órbita/ponto 174/111, que abrange os municípios Ariquemes, Jaru, Ouro Preto do Oeste, Rio Crespo, Cujubim, Ji-Paraná, Vale do Anari, Theobroma, Machadinho do Oeste, Cacaulândia, Vale do Paraíso, localizados na porção nordeste do Estado de Rondônia (Figura 1). Na parte leste da área de estudo encontra-se a Reserva Biológica do Jaru, no município de Ji-Paraná, com uma área de 346.864,20 hectares, criada a partir do decreto $n^{\circ} 83.716$, de 1979 (ICMBIO, 1999). 
Figura 1. Localização da área de estudo na porção nordeste do Estado de Rondônia, correspondente a órbita/ponto 174/111, satélite CBERS 4 - MUX.

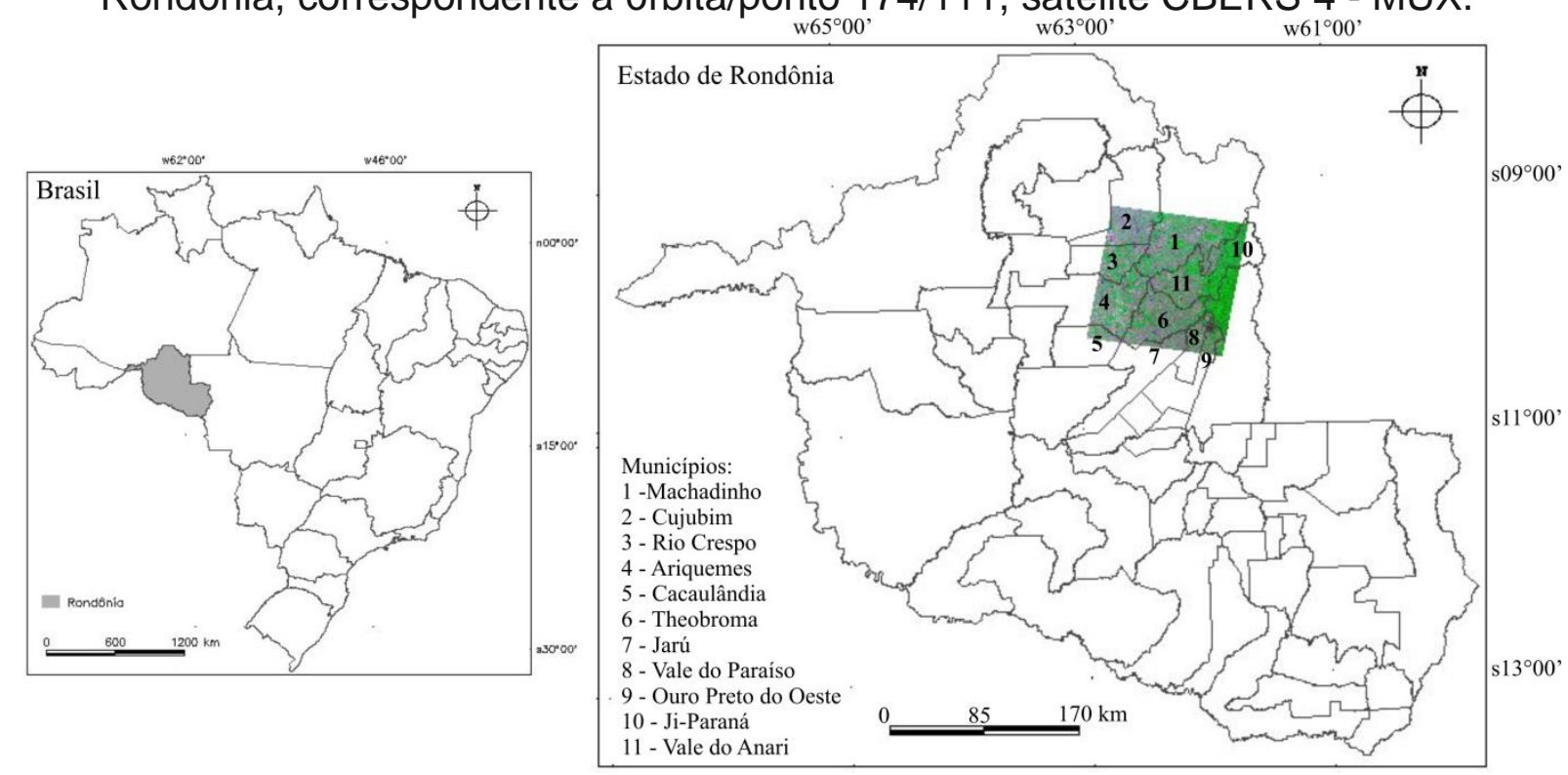

Fonte: Dados vetoriais - IBGE, 2019; CBERS 4 - MUX - INPE, 2019.

O clima da região é predominantemente quente e úmido com precipitações elevadas, porém, a precipitação total anual compensa a ocorrência de uma estação seca, possibilitando a existência de florestas tropicais. A vegetação é formada por Floresta Fluvial predominante com cobertura vegetal do tipo Floresta Tropical Aberta com Palmeiras. A Floresta Ombrófila Densa ou Aberta está situada entre os 4ํำ de latitude Norte e os 16을 latitude Sul, entre 100 e 600 m de altitude.

\section{COLETA E ANÁLISE DE DADOS}

Os dados para a identificação de focos de incêndios foram obtidos através do banco de dados de queimadas do Instituto Nacional de Pesquisas Espaciais (INPE) Programa Queimadas, o qual permite gratuitamente, em modo interativo, realizar análises espaciais e temporais de focos de queimadas e incêndios florestais detectados operacionalmente sobre a América Latina por meio de imagens de satélites (INPE, 2019).

Para a coleta de dados foi utilizado o satélite de referência AQUA_M-T (sensor MODIS) (INPE, 2019). Com o objetivo de obter a localização dos focos de incêndio no período seco nos anos de 2018 e 2019 filtrou-se o período para os meses de julho, agosto e setembro destes anos. Os dados foram exportados em formato shapefile e inseridos em um banco de dados no SPRING 5.5.6. Para o auxílio na interpretação dos mapas de focos de incêndio, foi realizada a aquisição dos mapas de precipitação observada, através do banco de dados de monitoramento climático, fornecidos gratuitamente pelo site do Instituto Nacional de Meteorologia (INMET), onde foram selecionados os meses de julho, agosto e setembro de 2018 e 2019.

Para realizar a avaliação de cicatrizes ocasionadas pelas queimadas, foram obtidas imagens do satélite CBERS 4, sensor MUX (resolução espacial de 20 m), no período de julho, agosto e setembro de 2019, órbita ponto 174/111, disponibilizadas gratuitamente no portal da Divisão de Processamento de Imagens - DPI/INPE. Para a escolha das datas das imagens levou-se em consideração os meses mais secos do ano na região, entre julho e setembro, e após verificação no banco de dados de 
queimadas, por ser o período em que ocorre a maior parte dos incêndios florestais. Além disso, buscou-se adquirir imagens que apresentassem baixas ou nenhuma cobertura de nuvens, o que foi possível devido ao baixo índice de precipitação nesse período no local (LOMBARDI, 2003). Porém, no mês de setembro houve a presença de nuvens cobrindo a parte superior da imagem, sendo esta porção excluída da avaliação de cicatrizes.

Todas as etapas de processamento das imagens foram realizadas no software SPRING 5.5.6. Após a aquisição, as imagens foram importadas no formato TIFF/GEOTIFF ( ${ }^{*}$.tiff) para o software. Já que as imagens utilizadas possuem correção geométrica feita pelos seus provedores e não apresentaram erros causados por falhas de detectores, não foi necessário submetê-las a nenhum procedimento de préprocessamento, ou seja, não foi realizado nenhum tipo de operação para a correção radiométrica, geométrica e atmosférica.

Posteriormente associou-se às bandas 7 (vermelho), 8 (infravermelho próximo), 6 (verde) as cores $\mathrm{R}, \mathrm{G}$ e $\mathrm{B}$ respectivamente, obtendo-se então a composição colorida para as três datas. Esta composição colorida auxiliou na identificação dos alvos de interesse, os quais possuem respostas espectrais diferentes em cada uma das bandas utilizadas e se apresentam em tonalidades de cores diferentes de acordo com a banda associada ao sistema RGB. Na composição colorida foi aplicado o realce de contraste linear, com o objetivo de melhorar a qualidade visual da imagem, além de facilitar a discriminação do visual dos alvos (PONZONI, 2012).

Para a extração de informações das imagens, utilizou-se o método de classificação supervisionada pixel a pixel em duas fases, sendo elas o treinamento e a classificação propriamente dita. $\mathrm{Na}$ fase de treinamento foi realizada a coleta de um conjunto de pixels representativos de cada classe de uso e cobertura da terra, e em seguida, agrupamentos de todos os pixels da imagem a ser classificada, em sua respectiva classe espectral (MOREIRA, 2011). Utilizou-se o algoritmo de Máxima Verossimilhança - MaxVer, no qual cada pixel é atribuído à classe mais provável. Portanto, para um pixel $x$ do espaço multiespectral, um conjunto de probabilidades é computado, efetuando as possibilidades relativas de o pixel pertencer a cada classe disponível (VALE, et. al., 2018). Foi considerado um limiar de aceitação de $100 \%$, resultando em uma imagem classificada sem rejeição, portanto, todos os pixels foram classificados (INPE, 2006). As classes temáticas definidas para a classificação foram: área sem cobertura vegetal, corpo d'água, cobertura vegetal e cicatrizes de incêndio. A definição das classes temáticas foi feita a partir da análise visual da imagem.

A edição final dos mapas foi realizada pelo componente SCarta disponível no pacote do sistema SPRING.

A identificação de cicatrizes de incêndios na região nordeste do Estado de Rondônia que foram atingidas por fogo no período de julho, agosto e setembro de 2019 , foi realizada a partir dos mapas de uso e cobertura da terra. Durante o processo de classificação das imagens foram coletadas amostras de áreas nitidamente atingidas pelo fogo e agrupou-as em uma classe denominada cicatrizes. Para auxiliar na identificação das cicatrizes de incêndios e principalmente validar as áreas realmente atingidas, durante a fase de treinamento no processo de classificação foi utilizado dados de focos de calor detectados pelo satélite de referência obtidos junto ao banco de dados do INPE, através do sistema de monitoramento de queimadas. 


\section{RESULTADOS E DISCUSSÃO}

\section{AVALIAÇÃO DOS FOCOS DE INCÊNDIO}

A partir dos dados disponibilizados pelo INPE, quanto ao número e localização dos focos de incêndios, foi possível constatar um pequeno aumento de focos em Rondônia no mês de julho de 2019 (780 focos) quando comparado ao mesmo período de 2018 (769 focos). Na área de estudo observou-se que em julho de 2018 os focos localizaram-se principalmente na porção oeste da cena (Figura 2), com maior concentração (35 focos) principalmente na cidade de Cujubim, próximo à divisa com Rio Crespo. Na reserva biológica do Jaru, abrangida pela área de estudo, ocorreu apenas 1 foco (considerando buffer de $10 \mathrm{~km}$ ) em 2018 (INPE, 2019).

Figura 2. Espacialização dos focos de incêndio na porção nordeste do Estado de

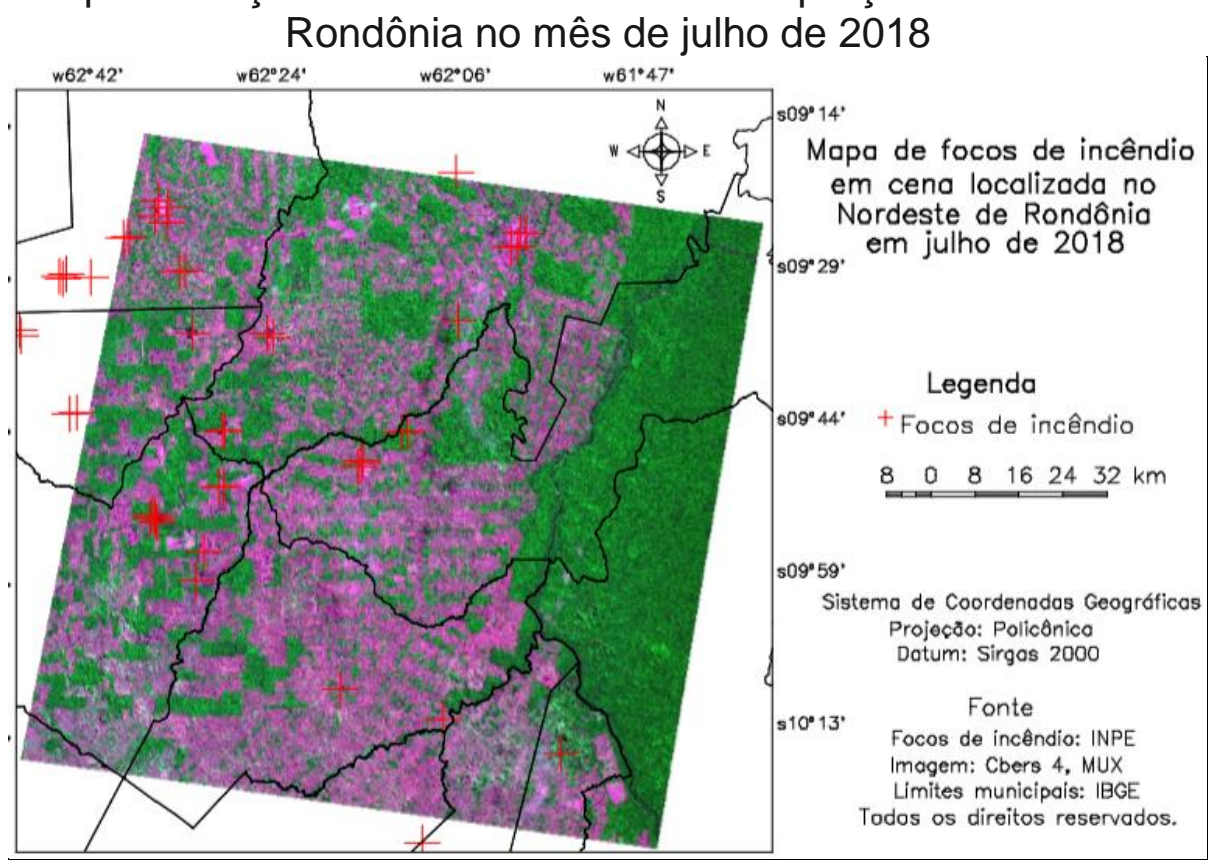

Fonte: Elaboração dos autores, 2019.

No mês de julho de 2019 houve aumento dos focos detectados na porção sul, próximos a reserva biológica do Jaru (Figura 3). A maior concentração de focos (59) ocorreu principalmente na divisa entre o município de Ouro Preto do Oeste e o município do Vale do Paraíso, sendo Ouro Preto do Oeste o município com maior número de focos (23) na área estudada. Na reserva biológica do Jaru ocorreram 3 focos (considerando buffer de $5 \mathrm{~km}$ ) em 2019 (INPE, 2019)

Contudo, é importante ressaltar que a relação foco x queimada não é direta quando se trata de imagens de satélite, já que um foco identifica a existência de fogo em um pixel, variando de $1 \mathrm{~km} \times 1 \mathrm{~km}$ até $5 \mathrm{~km} \times 4 \mathrm{~km}$. Dessa forma, é possível que haja neste pixel uma ou diversas queimadas distintas. Além disso, se uma queimada for extensa, ela será detectada em alguns pixels próximos, assim, vários focos estarão associados a um único incêndio (INPE, 2007). 
Figura 3. Espacialização dos focos de incêndio na porção nordeste do Estado de Rondônia no mês de julho de 2019.

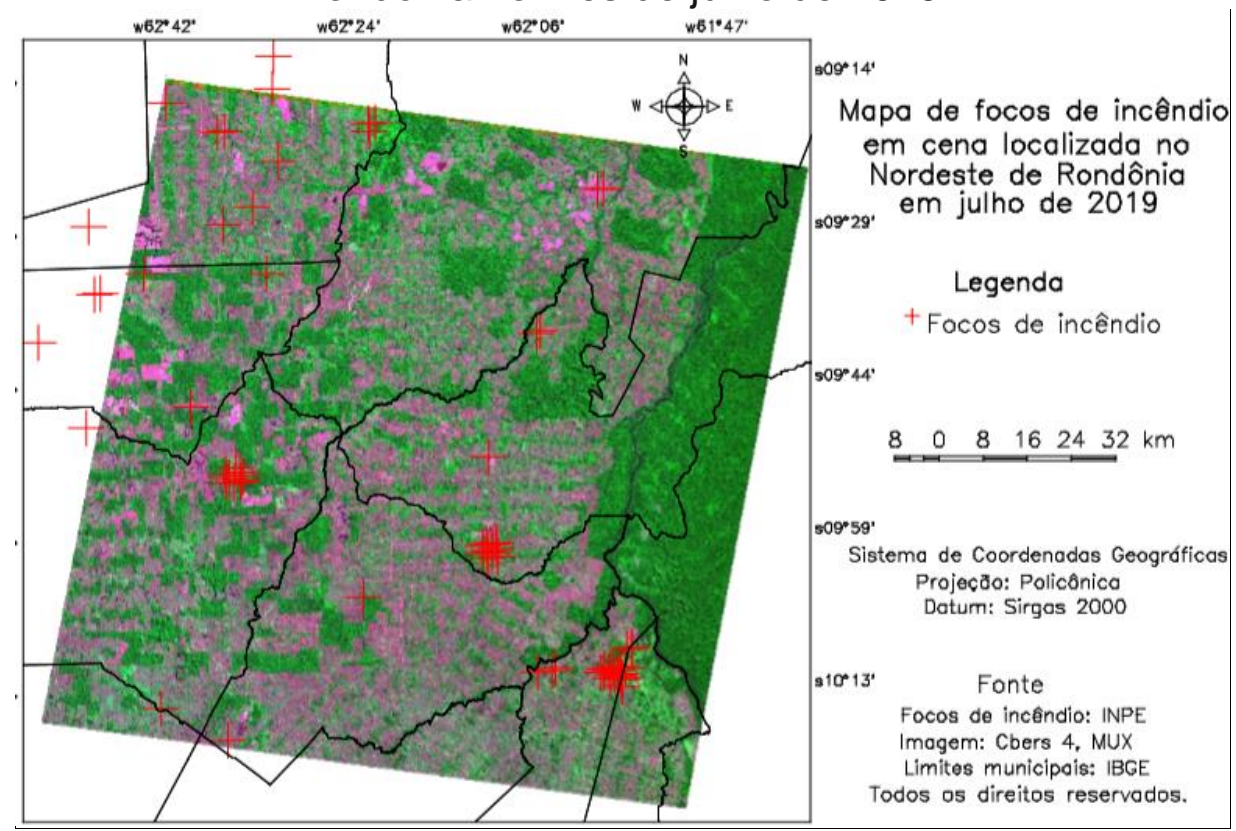

Fonte: Elaboração dos autores, 2019

No mês de agosto de 2018, o número de focos de incêndio em Rondônia foi 1.975, já no ano de 2019 foram detectados 5.592 focos. Na reserva biológica do Jaru, foram identificados 25 focos em 2018, e 37 focos no ano seguinte, considerando um buffer de $5 \mathrm{~km}$ (INPE, 2019). Na área de estudo foram detectados 130 focos em 2018, localizados principalmente na porção norte do município de Ouro Preto do Oeste em divisa com o município do Vale do Paraíso, onde se concentraram 70 focos de incêndio (Figura 4).

Figura 4. Espacialização dos focos de incêndio na porção nordeste do Estado de Rondônia no mês de agosto de 2018

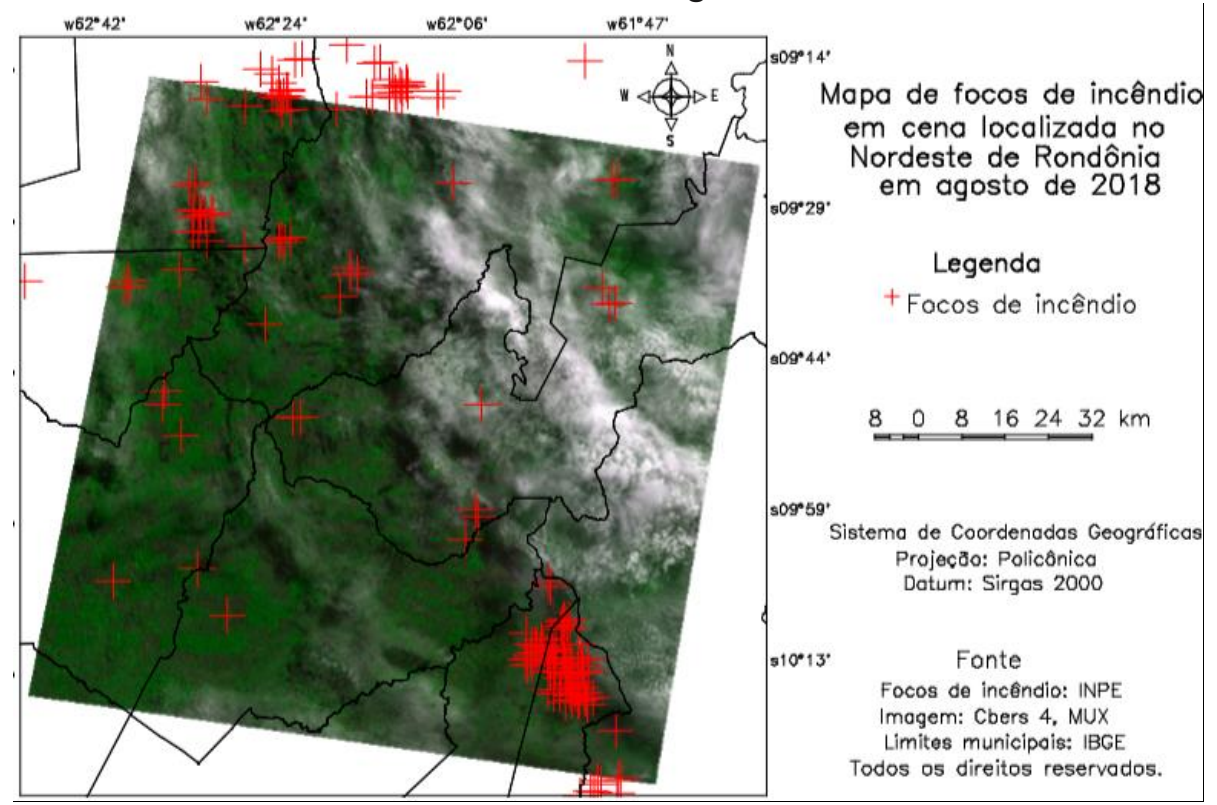

Fonte: Elaboração dos autores, 2019 
No ano de 2019 observou-se 319 focos, concentrados na porção norte do município de Ouro Preto do Oeste, onde foi observado um aglomerado de 75 focos de incêndio, e no município de Machadinho, com 72 focos (Figura 5).

Figura 5. Espacialização dos focos de incêndio na porção nordeste do Estado de Rondônia no mês de agosto de 2019

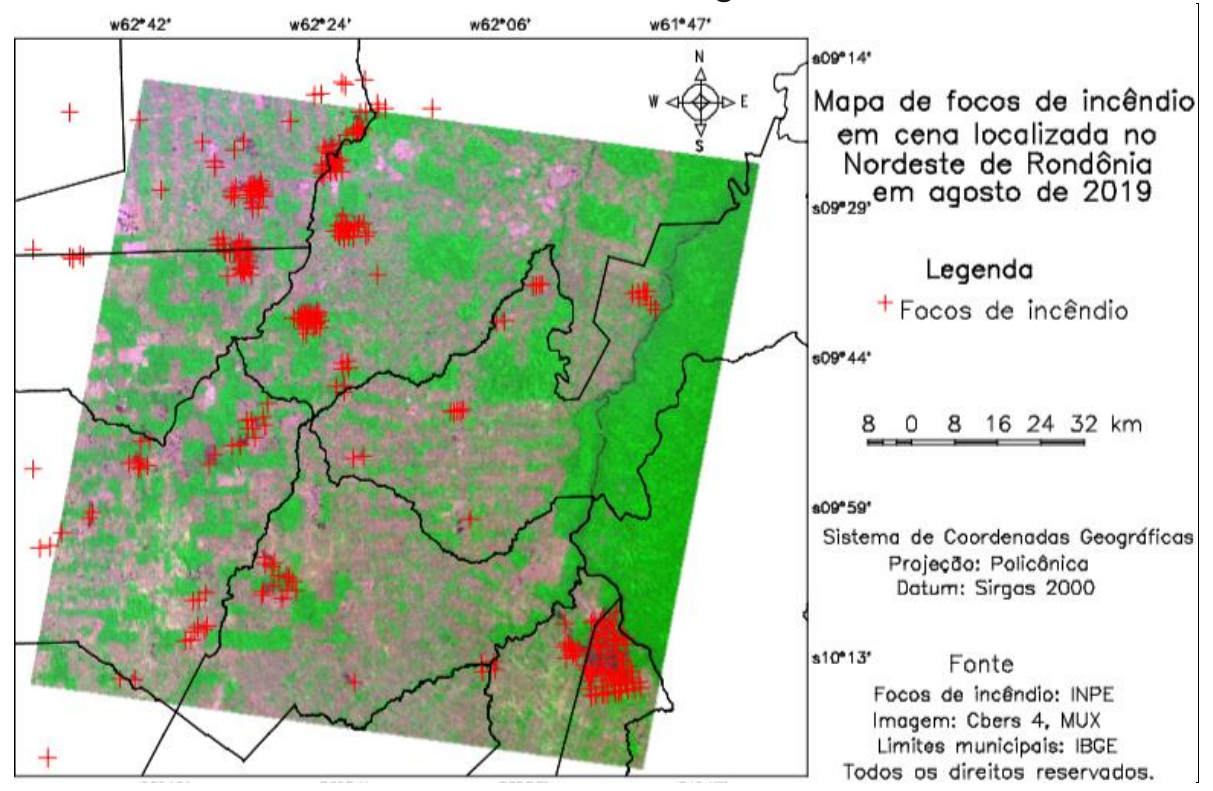

Fonte: Elaboração dos autores, 2019

Os dados obtidos para o mês de agosto mostram um grande aumento de focos de incêndios no Estado de Rondônia em relação ao mês de julho em ambos os anos. Quando comparado somente os meses de agosto de 2018 e 2019 é possível observar um aumento de focos de incêndios quase três vezes maior em 2019.

No mês de setembro, diferentemente dos meses anteriores, o ano de 2018 teve um número muito maior de focos de incêndio em Rondônia do que no ano de 2019. De acordo com o INPE, o número de focos de incêndio em Rondônia no mês de setembro do ano de 2018 foi 6.032 , enquanto no ano de 2019 ocorreram 3.644 focos. $\mathrm{Na}$ reserva biológica do Jaru, no ano de 2018 foram identificados 37 focos (considerando buffer de $5 \mathrm{~km}$ ) e no ano seguinte 28 focos (considerando buffer de 5 km) (INPE, 2019). Na área de estudo foram detectados 370 focos em 2018 (Figura 6), localizados principalmente no município de Machadinho, com 124 focos.

Em 2019 identificou-se 381 focos (Figura 7) na área de estudo, localizados principalmente no município de Machadinho (122 focos). Ainda, observou-se que os focos localizados na porção norte do município de Ouro Preto do Oeste em divisa com o município do Vale do Paraíso, na porção sul da cena, também foram detectados no mês de setembro. 
Figura 6. Espacialização dos focos de incêndio na porção nordeste do Estado de Rondônia no mês de setembro de 2018

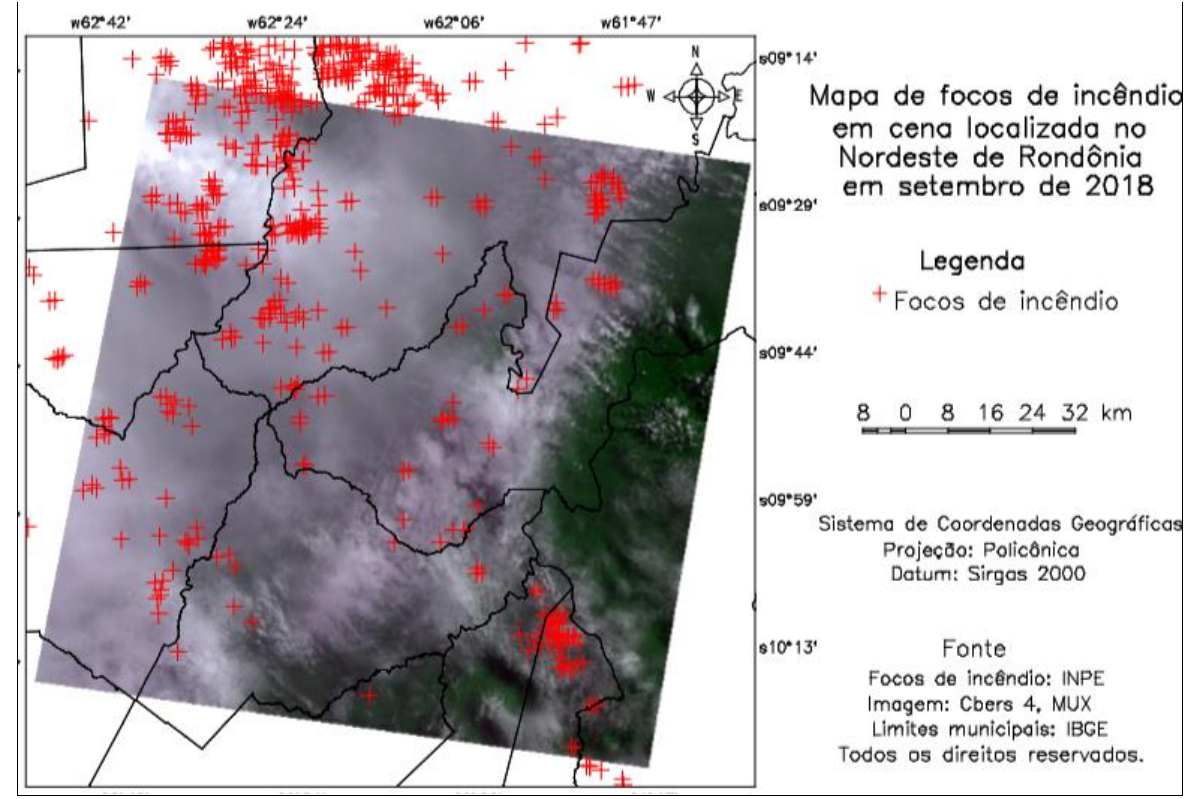

Fonte: Elaboração dos autores, 2019

Figura 7. Espacialização dos focos de incêndio na porção nordeste do Estado de Rondônia no mês de setembro de 2019.

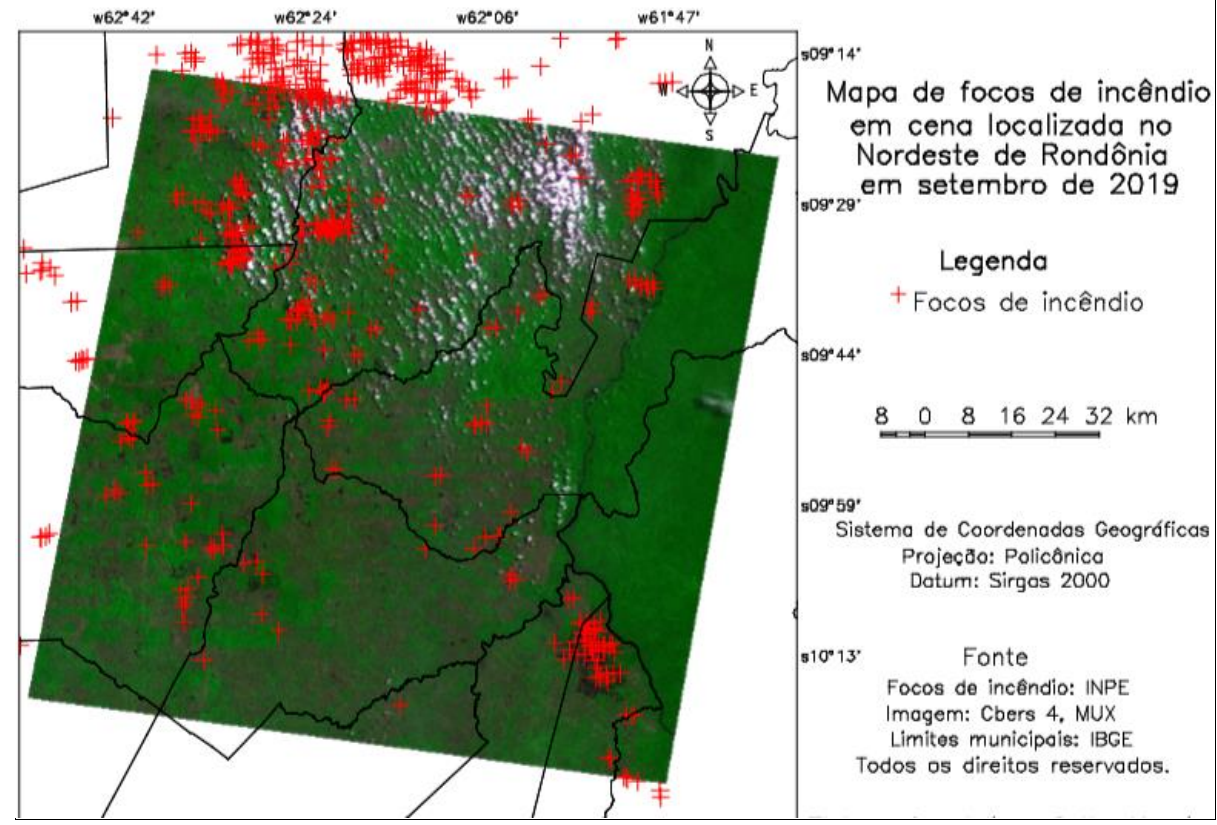

Fonte: Elaboração dos autores, 2019

De forma geral é possível observar o aumento de focos de queimadas na área de estudo no ano de 2019 em comparação a 2018, sendo que, em todos os meses avaliados, o mês de setembro de 2019 foi o período com maior número de focos (Figura 8). Ademais, nos municípios de Ouro Preto do Oeste e Machadinho foram detectadas as maiores concentrações de focos de incêndios, em todos os períodos. 
Figura 8. Comparativo do número de focos de incêndio na área de estudo no período avaliado.

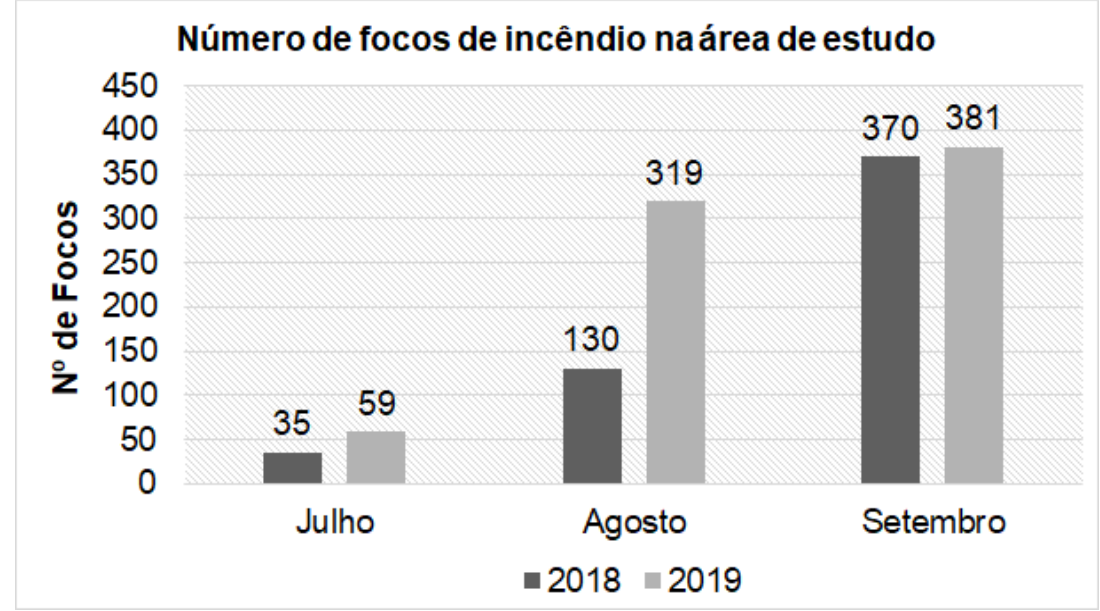

Fonte: Elaboração dos autores, 2019

Quanto às condições de tempo, em julho de 2018 (Figura 9a) a precipitação ficou acima da normal climatológica especialmente no norte da Região Norte. Em Rondônia, a precipitação variou de dentro da normalidade a pouco abaixo da normal climatológica (INMET, 2018a). Já no ano de 2019, o mapa evidenciou um período um pouco mais seco na região (Figura 9b). Porém, é interessante observar que as regiões mais secas de Rondônia nesse período localizadas ao Sul e Centro-Sul do estado de Rondônia, não se referem aos locais que se concentram o maior número de focos de incêndios, observados principalmente na região Norte e Noroeste.

Figura 9. Precipitação observada no Brasil no mês de julho de 2018 (a) e 2019 (b).

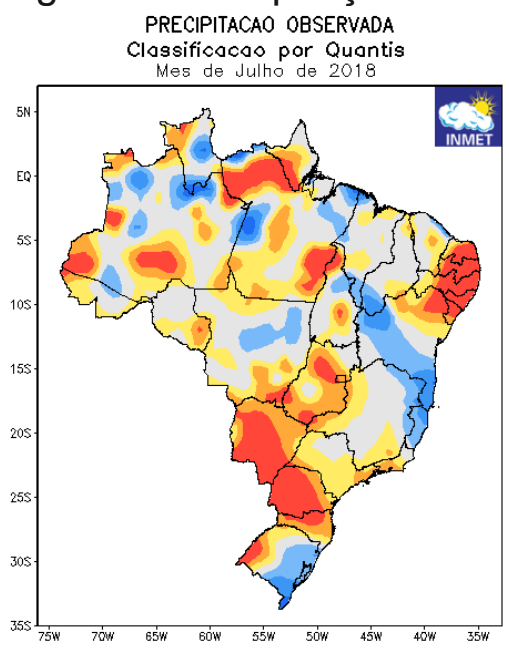

(a)

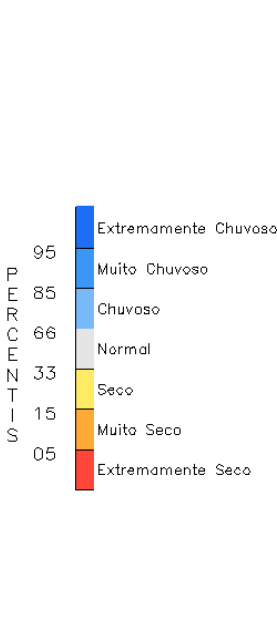

Fonte: INMET, 2019.

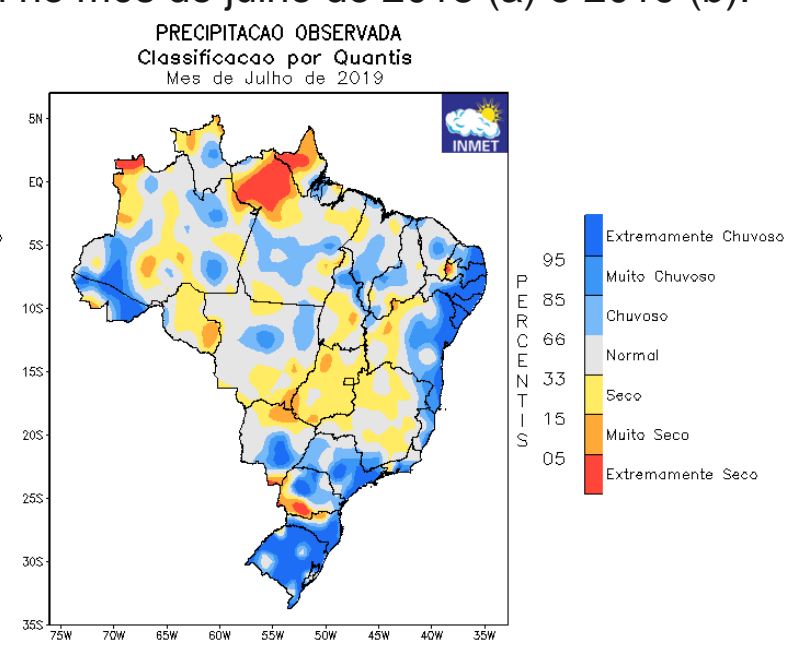

(b)

No período de agosto de 2018, a precipitação apresentou uma distribuição irregular, porém, com chuvas dentro da normalidade na maior parte da Região Norte do Brasil. Em Rondônia, foi observado chuvas acima da média do mês. Neste mês, as chuvas já são mais escassas pela região, sendo o início da estação menos chuvosa do Norte do país (INMET, 2018b). Em 2019, é possível observar (Figura 11b) que o mês de agosto foi mais seco do que o ano anterior (Figura 11a). Neste mês, assim como o mês de julho, ocorre a concentração de focos de incêndio na região noroeste 
e norte do Estado, regiões estas que não apresentam o clima seco, como na porção Sul e Centro-Sul de Rondônia.

Figura 10. Precipitação observada no Brasil no mês de agosto de 2018 (a) e 2019

(b).

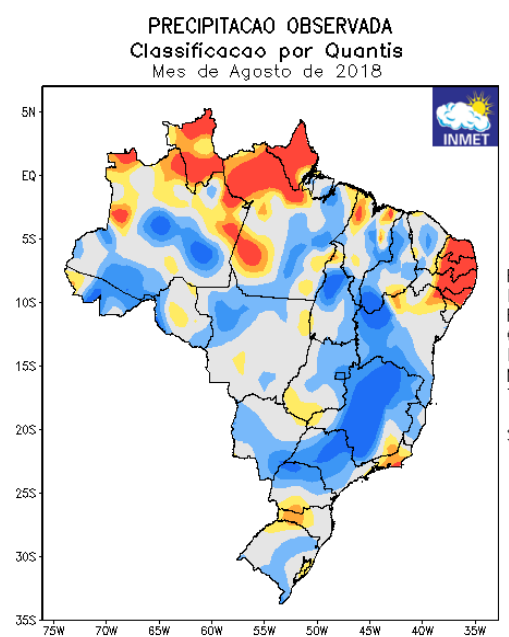

(a)

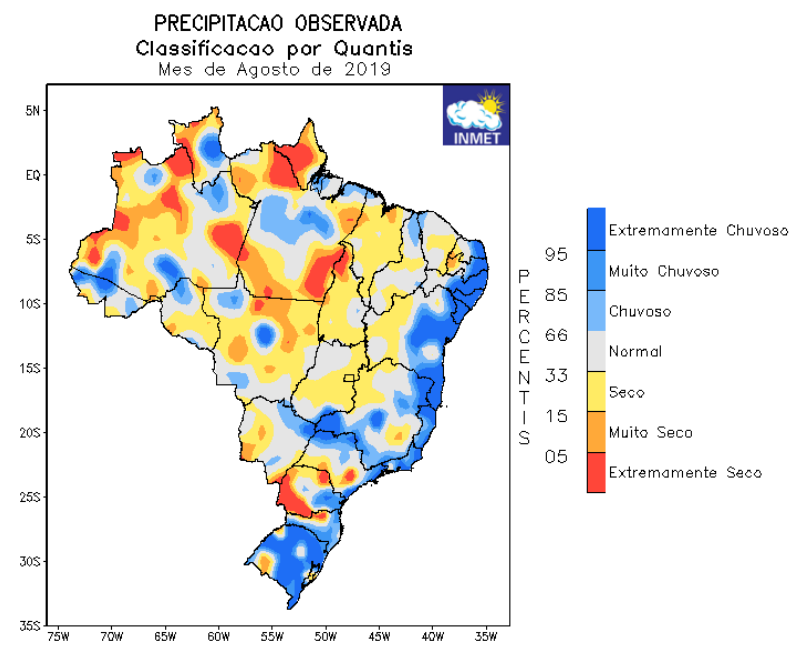

(b)

Fonte: INMET, 2019.

Em setembro de 2018, a precipitação na região variou de dentro da normalidade a pouco abaixo da normal climatológica. O número de dias com chuva variou de 1 até 19 dias (INMET, 2018c). Já em 2019, o mês de setembro apresentouse muito mais seco do que o ano anterior, como pode ser observado nas figuras $12 \mathrm{a}$ e $12 b$.

Figura 12. Precipitação observada no Brasil no mês de setembro de 2018 (a) e 2019

(b).

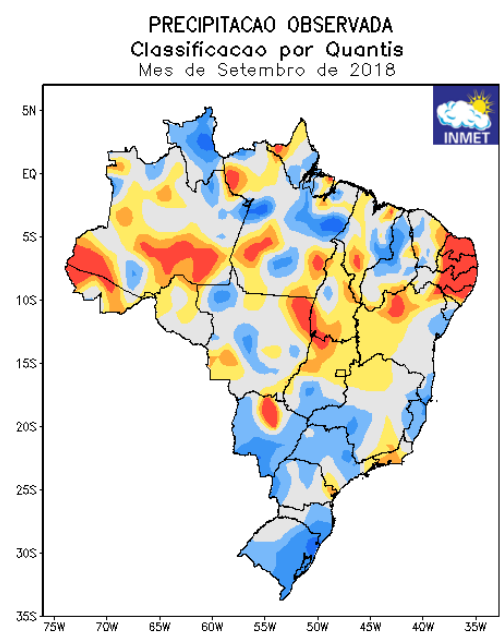

(a)

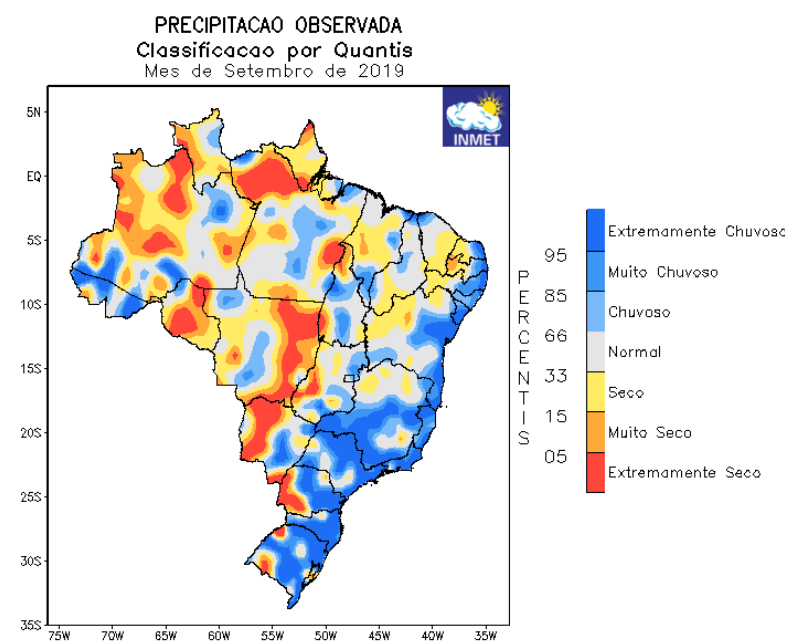

(b)

Fonte: INMET, 2019 
Os resultados obtidos a partir do mapeamento do uso e cobertura da terra para a cena localizada no nordeste de Rondônia permitiram identificar a presença de cicatrizes em todos os meses analisados (julho, agosto e setembro) de 2019.

No mês de julho de 2019 (Figura 13), as cicatrizes apareceram em menor quantidade em relação aos dois meses seguintes. Este resultado era esperado, já que nos meses seguintes (agosto e setembro) houve quantidades maiores de focos de incêndio. Em julho de 2019 a técnica de classificação MaxVer utilizada neste estudo detectou uma área total de 15.571,08 hectares de cicatrizes de incêndios florestais, visualizadas principalmente na porção norte da cena. No entanto, essas cicatrizes possivelmente não se referem somente aos focos detectados no mês de julho, podendo corresponder aos focos de meses anteriores, uma vez que são registradas as cicatrizes após a ocorrência do incêndio.

Figura 13. Mapa de uso da terra em recorte localizado no nordeste de Rondônia no

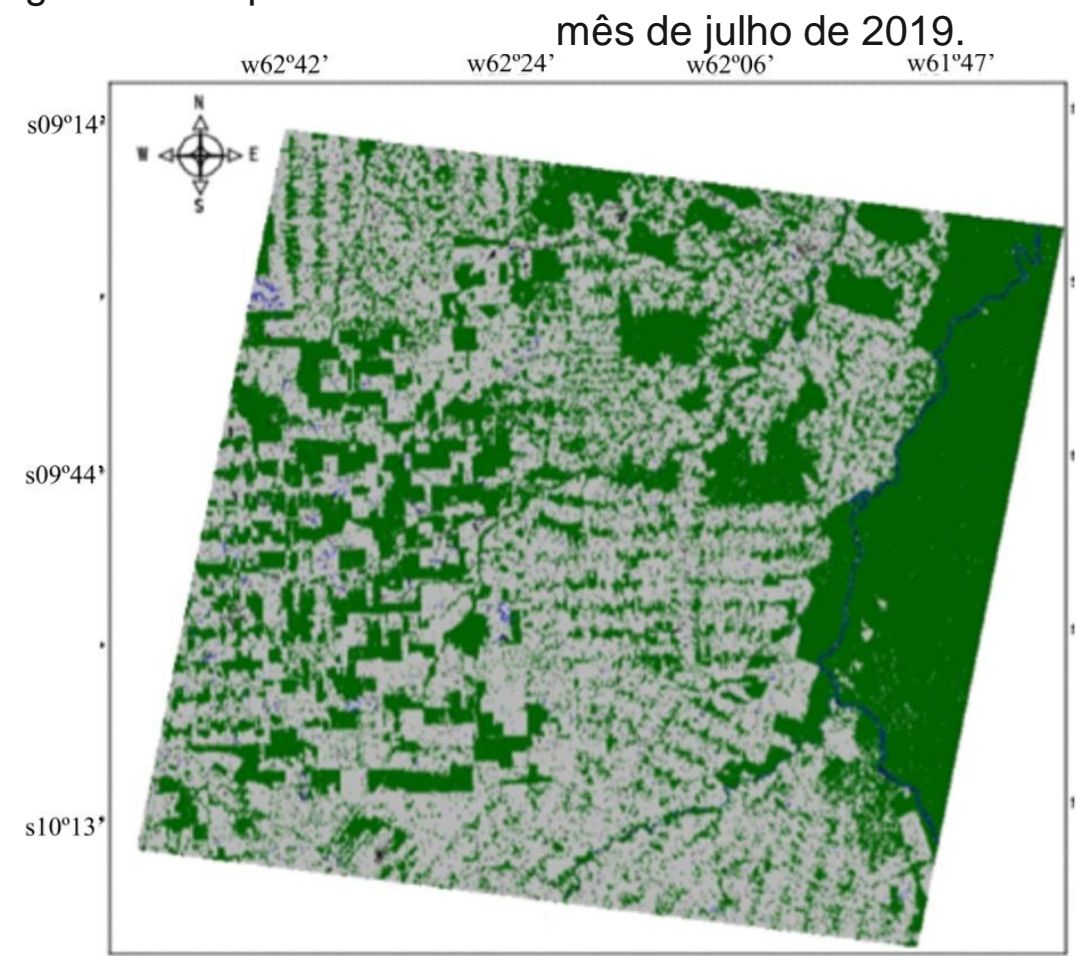

Mapa de uso da terra em cena localizada no

Nordeste de Rondônia em julho de 2019

Fonte: Elaboração dos autores, 2019

Legenda:

- Cicatrizes de incêndio

Cobertura vegetal

Área sem cobertura vegetal

Corpo d'água

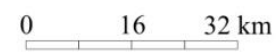

Sistema de Coordenadas Geográficas Datum SIRGAS 2000.

Fonte:

Focos de incêndio - INPE.

Imagem CBERS 4, 2019.

A partir do mês de agosto de 2019 é possível observar o aparecimento de cicatrizes extensas comparada ao mês anterior. A classificação de imagem detectou uma área total de 38.273,16 hectares de cicatrizes de incêndios florestais para o mês de agosto (Figura 14), sendo mais que o dobro do mês anterior. 
Figura 14. Mapa de uso da terra em recorte localizado no nordeste de Rondônia no

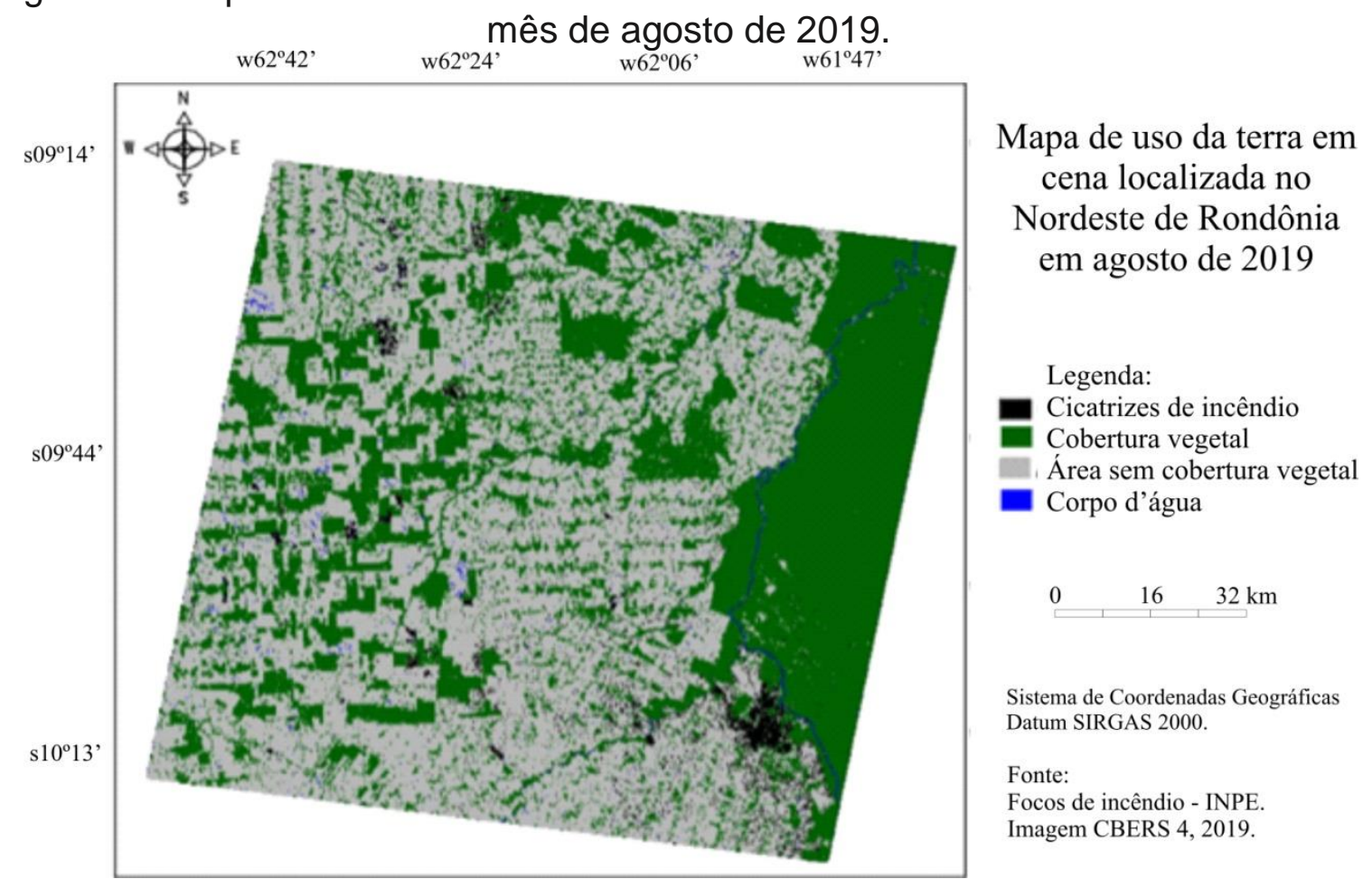

Fonte: Elaboração dos autores, 2019

A cicatriz mais extensa está localizada na porção sudeste da área de estudo, sendo nesta área, o local onde estava concentrado o maior número de focos de incêndio dessa cena neste mês (agosto) e no mês de julho. Durante o processamento da imagem foi possível observar alguns focos ainda ativos e a fumaça resultante no momento da aquisição da imagem pelo sensor (Figura 15).

Figura 15. Foco de incêndio e fumaça em área de cicatriz no nordeste de Rondônia.

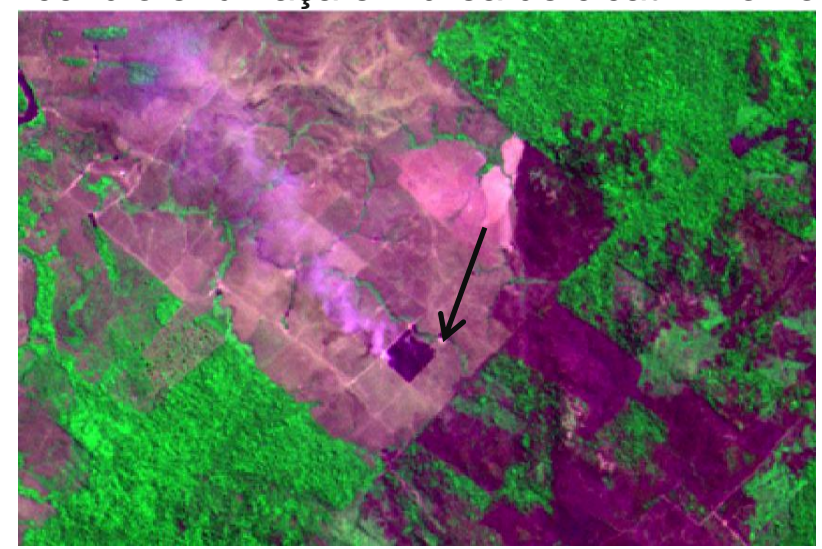

Fonte: Imagem CBERS 4 MUX - agosto 2019

Já no mês de setembro não foi possível observar se houve o aumento de cicatrizes em relação à julho e agosto devido à presença de nuvens em grande parte da imagem, sendo necessário realizar o recorte da parte superior da cena. Neste período, foi detectada uma área total de $13.798,28$ hectares de cicatrizes de incêndios florestais na metade da imagem onde foi viável realizar a classificação supervisionada (Figura 16). Neste mês ainda foi possível identificar a cicatriz registrada no mês de agosto, no sudeste da cena. 
Figura 16. Mapa de uso da terra em recorte localizado no nordeste de

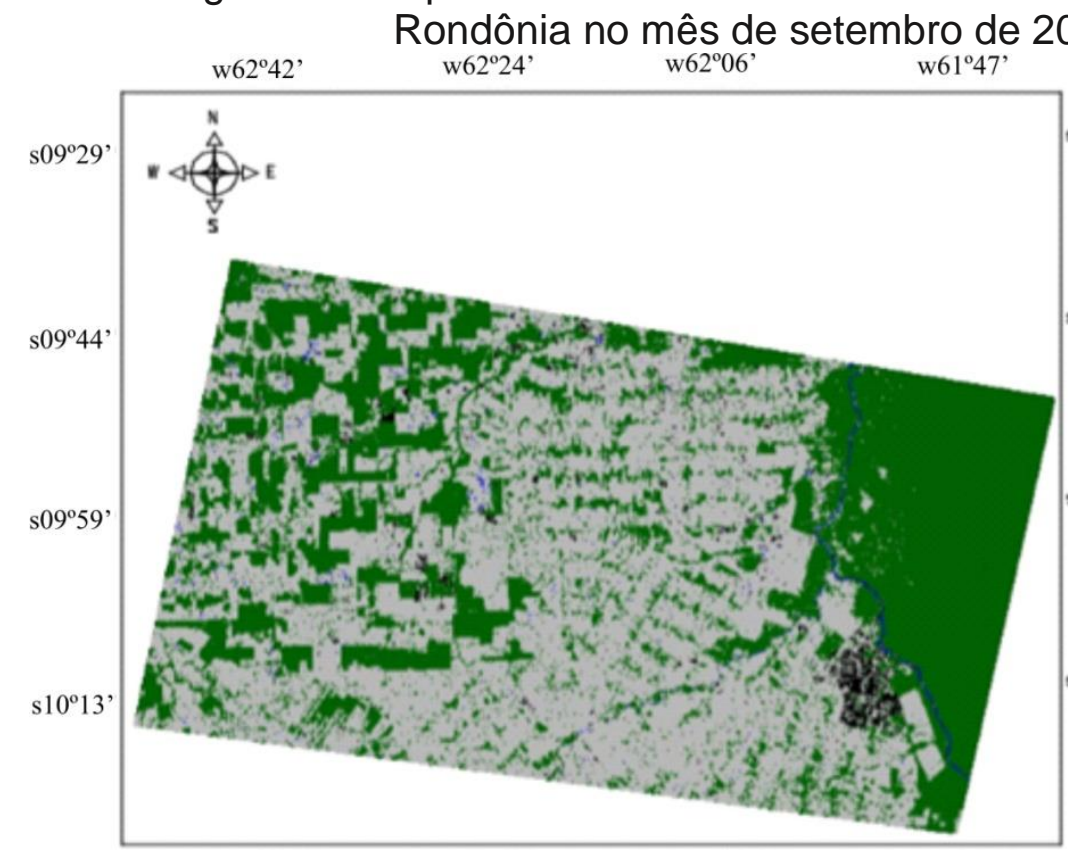

Fonte: Elaboração dos autores, 2019
Mapa de uso da terra em cena localizada no Nordeste de Rondônia em setembro de 2019

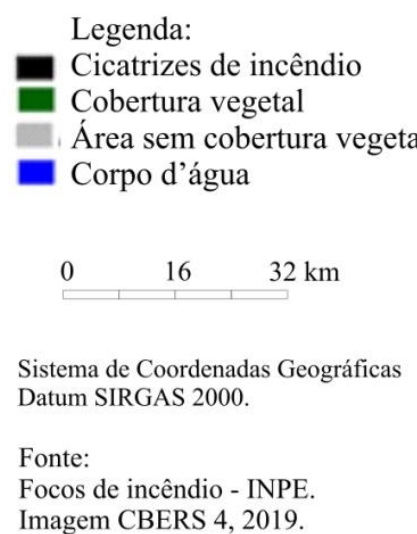

Em todos os períodos analisados, as cicatrizes de incêndios estão localizadas no encontro entre a vegetação nativa e o solo descoberto (oriundos de desmatamento ou de atividades agropecuárias). Este resultado demonstra um indício de queima provocada por ação antrópica, já que o uso das queimadas em áreas de pastagens é uma prática de manejo tradicional na área rural amazônica. Homma et al. (1993) comenta que o fogo é utilizado para remover os vegetais não palatáveis para os bovinos, estimular o crescimento do pasto, controlar pragas, entre outros. Além disso, áreas em que já ocorreu a extração madeireira e da floresta densa ou capoeira localizadas nos limites dos "mosaicos" de pastagens são mais propensas aos incêndios florestais (UHL; BUSCHBACHER, 1991). Ademais, a técnica de utilizar a queima para a formação das pastagens traz a deposição de cinzas no solo como um grande benefício para este fim, além de ser mais econômico em comparação à utilização de tratores (NEPSTAD; MOREIRA; ALENCAR, 1999).

Em todo o período avaliado, os focos de calor disponibilizados pelo banco de dados de queimadas do INPE foram importantes para auxiliar tanto na localização das cicatrizes, quanto na validação das áreas realmente atingidas.

Avaliando os mapas de focos de incêndios e o uso de terra, é possível observar o grande aumento de queimadas no mês de agosto e como isso resultou na alteração da paisagem no local. Esse fato evidencia a necessidade da prevenção de queimadas no bioma.

Assim, como uma grande parte das queimadas que ocorrem na Amazônia são incêndios florestais decorrentes de áreas derrubadas de florestas densas, capoeiras, restos de práticas agrícolas, e queimadas acidentais ou criminosas, é necessário pesquisar técnicas e métodos mais apropriados de controle dessa prática agrícola (HOMMA et. al., 1993). 


\section{CONCLUSÃO}

A análise temporal e espacial dos focos de incêndios permitiu identificar o aumento da quantidade de focos no período seco (julho, agosto e setembro) em 2019 quando comparado ao mesmo período no ano de 2018, onde as cidades de Machadinho e Ouro Preto do Oeste obtiveram as maiores ocorrências de focos em todo o período estudado. Todavia, a partir dos dados de precipitação do estado de Rondônia, foi possível observar que as causas dos focos podem não estar somente relacionadas ao clima seco.

A análise espacial e temporal de uso e cobertura da terra, utilizando imagens do satélite CBERS 4 - MUX demonstrou que ocorreram mudanças bruscas na paisagem na transição entre os meses de julho e agosto de 2019. Observaram-se extensas cicatrizes de queimadas, principalmente na divisa dos municípios de Ouro preto do Oeste e Vale do Paraíso em agosto, o que não ocorria no mês anterior. Entretanto, mesmo o mês de setembro de 2019, sendo o período de maior extensão de cicatrizes, não houve grandes mudanças na paisagem em comparação a agosto.

De forma geral, as cicatrizes de incêndios foram localizadas no encontro entre a vegetação nativa e o solo descoberto (oriundos de desmatamento ou de atividades agropecuárias), sendo esse um indício de queima antrópica, já que a literatura aponta essa prática como cultural na região. Fato esse que merece maior atenção das autoridades para avaliar meios apropriados de controle dessa prática.

\section{REFERÊNCIAS BIBLIOGRÁFICAS}

BATISTA, A. C. Detecção de incêndios florestais por satélite. Revista Floresta, v. 34, n. 2, p. 237-241, 2004.

BRASIL. Decreto n. 2.661, de 8 de julho de 1998. Regulamenta o $\S$ único do art. 27 da Lei 4.771, de 15 de setembro de 1965 (Código Florestal), mediante o estabelecimento de normas de precaução relativas ao emprego do fogo em práticas agropastoris e florestais, e dá outras providências. Disponível em: <http://www.planalto.gov.br/ccivil_03/decreto/D2661.htm>. Acesso em: 11 de novembro de 2019.

BRASIL. Lei Federal № 9.985, de 18 de julho de 2000. Regulamenta o art. 225, § 10, incisos I, II, III e VII da Constituição Federal, institui o Sistema Nacional de Unidades de Conservação da Natureza e dá outras providências. Disponível em: <http://www.planalto.gov.br/ccivil_03/leis/L9985.htm>. Acesso em: 10 de novembro de 2019

EMPRESA BRASILEIRA DE PESQUISA AGROPECUÁRIA - EMBRAPA. AQUA Aqua Project Science. 2019. Disponível em: $<$ https://www.cnpm.embrapa.br/projetos/sat/conteudo/missao_aqua.html. Acesso em: 27 de agosto de 2019.

HOMMA, A. K. O. et. al. A dinâmica dos desmatamentos e das queimadas na Amazônia: uma análise microeconômica. In: Congresso Brasileiro de Economia e Sociologia Rural, 31. Ilhéus. Anais... Brasília, DF: SOBER, 1993. p. 663-676.

INSTITUTO CHICO MENDES DE CONSERVAÇÃO DA BIODIVERSIDADE - ICMBio. 
Dados Geoestatísticos das Unidades de Conservação Federais: Área das Unidades de Conservação Federais por categoria de julho de 2019. Disponível em: $<w w w$.icmbio.gov.br/portal/images/stories/servicos/geoprocessamento/DCOL/dados tabulares/\%C3\%81rea_UC_federais_categoria_julho_2019.pdf> Acesso em: $\overline{0} 1 / 10 / 2019$.

INSTITUTO NACIONAL DE METEOROLOGIA - INMET. Boletim Agroclimatológico Mensal. Brasília: INMET. n. 7. v. 53, 2018.

INSTITUTO NACIONAL DE METEOROLOGIA - INMET. Boletim Agroclimatológico Mensal. Brasília: INMET. n. 8. v. 53, 2018.

INSTITUTO NACIONAL DE METEOROLOGIA - INMET. Boletim Agroclimatológico Mensal. Brasília: INMET. n. 9. v. 53, 2018.

INSTITUTO NACIONAL DE PESQUISAS ESPACIAIS - INPE. Banco de Dados de queimadas. 2019.

Disponível em:<http://queimadas.dgi.inpe.br/queimadas/portal/informacoes/perguntasfrequentes \#p6>. Acesso em: 25 de agosto de 2019.

INSTITUTO NACIONAL DE PESQUISAS ESPACIAIS - INPE. Banco de Dados de queimadas. Disponível em: <http://queimadas.dgi.inpe.br/queimadas/bdqueimadas>. Acesso em: 02 de outubro de 2019.

INSTITUTO NACIONAL DE PESQUISAS ESPACIAIS - INPE. Câmeras Imageadoras CBERS-3 e 4.2019. Disponível em: <http://www.cbers.inpe.br/sobre/cameras/cbers3-4.php>. Acesso em: 15 de outubro de 2019.

INSTITUTO NACIONAL DE PESQUISAS ESPACIAIS - INPE. Manuais - Tutorial de Geoprocessamento: Classificação de Imagens. 2006. Disponível em:<http://www.dpi.inpe.br/spring/portugues/tutorial/classific.html>. Acesso em: 14 de novembro de 2019.

LOMBARDI, R. J. R. Estudo da recorrência de queimadas e permanência de cicatrizes do fogo em áreas selecionadas do cerrado brasileiro, utilizando imagens TM/LANDSAT. 2003. 172 f. Dissertação (Mestrado em Sensoriamento Remoto) - Instituto Nacional de Pesquisas Espaciais, São Jose dos Campos, 2003.

MARTHA JUNIOR, G. B.; CONTINI, E.; NAVARRO, Z. Caracterização da Amazônia Legal e macrotendências do ambiente externo. Brasília, DF: Embrapa Estudos e Capacitação, 2011.

MOREIRA, M. A. Fundamentos do Sensoriamento Remoto e metodologias de aplicação. 4. ed. Viçosa: UFV, 2011. 422p.

NEPSTAD, D. C., A. MOREIRA; A. A. ALENCAR. 1999. A Floresta em Chamas: Origens, Impactos e Prevenção de Fogo na Amazônia. Programa Piloto para a Proteção das Florestas Tropicais do Brasil, Brasília, Brasil. p. 71. 
PONZONI, F. J.; SHIMABUKURO, Y. E.; KUPLICH, T. M. Sensoriamento Remoto da Vegetação. 2 ed. São Paulo: Oficina de Textos, 2012. 160 p.

UHL, C.; BUSCHBACHER, R. Queimada: O Corte que Atrai. Ciência Hoje, v. especial (Amazônia), p. 84-88. 1991.

VALE, J. R. B. et al. Análise comparativa de métodos de classificação supervisionada aplicada ao mapeamento da cobertura do solo no município de Medicilândia, Pará. Revista de Geografia e Interdisciplinaridade, p. 26-44, 2018. 